So far, the new material has provided steady performance for up to 1000 hours of operation in a small laboratory-scale SOFC. To be commercially viable, however, the material will have to be proven in operation for up to five years-the expected lifespan of a commercial SOFC.

"We don't see any problems ahead for fabrication or other issues that might prevent scale-up," said Liu, a Regent's professor in the School of Materials Science and Engineering at Georgia Tech. "The mate- rial is produced using standard solid-state reactions and is straightforward."

The researchers do not yet understand how their new material resists deactivation by sulfur and carbon, but theorize that it may provide enhanced catalytic activity for oxidizing sulfur and both cracking and reforming hydrocarbons.

Furthermore, Liu said, "Getting the temperature down to $300-400^{\circ} \mathrm{C}$ could allow use of much less expensive materials in the packaging, which would dramatically reduce the cost of these systems."

"Solid-oxide fuel cells offer high energy efficiency, the potential for direct utilization of all types of fuels including renewable biofuels, and the possibility of lower costs since they do not use any precious metals," said Liu. "We are working to reduce the cost of solid-oxide fuel cells to make them viable in many new applications, and this new material brings us much closer to doing that."

\section{Renewable Hydrogen Production Becomes Reality at Winery}

The first demonstration of a renewable method for hydrogen production from wastewater using a microbial electrolysis system is underway at the Napa Wine Company in Oakville, Calif. The refrigerator-sized hydrogen generator will take winery wastewater, and using bacteria and a small amount of electrical energy, convert the organic material into hydrogen and other products, according to B.E. Logan of the Pennsylvania State University.

"This is a demonstration to prove we can continuously generate renewable hydrogen and to study the engineering factors affecting the system performance," said Logan, Kappe professor of environmental engineering. "The hydrogen produced will be vented except for a small amount that will be used in a hydrogen fuel cell." Eventually, Napa Wine Company would like to use the hydrogen to run vehicles and power systems.

Napa Wine Company's wastewater comes from cleaning equipment, grape disposal, wine making, and other processes. The company already has on-site wastewater treatment and recycling and the partially treated water from the microbial electrolysis system will join other water for further treatment and use in irrigation.

"It is nice that Napa Wine Company offered up their winery and facilities to test this new approach," said Logan. "We chose a winery because it is a natural tourist attraction. People go there all the time to experience wine making and wine, and now they can also see a demonstration of how to make clean hydrogen gas from agricultural wastes."

The demonstration microbial electrolysis plant is a continuous flow system that will process about 1000 liters of wastewater a day. Microbial electrolysis cells consist of two electrodes immersed in liquid. Logan uses electrode pairs consisting of one carbon anode and one stainless steel cathode in his system rather than an electrode coated with a precious metal like platinum or gold. Replacing precious metals will keep down costs. The wastewater enters the cell where naturally occurring bacteria convert the organic material into ions including hydrogen ions. However, the currents produced by this process are limited because a fermentation barrier exists. The fermentation barrier can be overcome by a small applied electrical bias, on the order of $0.25 \mathrm{~V}$, so that hydrogen gas is produced electrochemically on the stainless steel cathode in a much more efficient manner.

The demonstration plant is made up of 24 modules. Each module has six pairs of electrodes.

"The composition of the wastewater will change throughout the year," said Logan. "Now it is likely to be rather sugary, but later it may shift more toward the remnants of the fermentation process."

The bacteria that work in the electrolysis cells will consume either of these organic materials.

The project is supported by Air Products \& Chemicals, Inc., The Water Environmental Research Foundation Paul L. Busch Award, and other donors. Brown \& Caldwell, an environmental engineering consulting firm, was contracted to build the demonstration plant. The Napa Wine Company is donating its facilities and wastewater for the demonstration.

\section{Advertisers in This Issue}

Page No.

*Across International LLC 783

\begin{tabular}{lr}
\hline *Asylum Research & Outside back cover \\
\hline Bruker & 777 \\
\hline${ }^{*}$ Carl Zeiss SMT Inc. & 784 \\
\hline *Goodfellow Corporation & 789 \\
\hline Hecus X-Ray Systems GmbH & 798,800 \\
\hline High Voltage Engineering & Inside front cover \\
\hline *HORIBA Scientific & 786 \\
\hline *Hysitron, Inc. & 793 \\
\hline International Centre for Diffraction Data (ICDD) & 799 \\
\hline *Janis Research Company, Inc. & 783 \\
\hline *JEOL USA, Inc. & 782 \\
\hline *Lake Shore Cryotronics, Inc. & 831 \\
\hline Magnequench Neo Power Pte Ltd & 846 \\
\hline *MDC Vacuum Products, LLC & 791 \\
\hline *MMR Technologies, Inc. & 785 \\
\hline
\end{tabular}

National Electrostatics Corporation

813

*NT-MDT Co.

Inside back cover

*Royal Society of Chemistry

847

*Sigma-Aldrich

794

Solarton Analytical

801

${ }^{*}$ Structure Materials Industries, Inc.

785

Tethis s.r.l.

831

*VAT, Inc.

837

*Veeco Instruments Inc.

778

*J.A. Woollam Company, Inc.

821

For free information about the products and services offered in this issue, check http://www.mrs.org/bulletin_ads.

*Please visit us at the Exhibit, December 1-3, during the 2009 MRS Fall Meeting in Boston. 